\title{
Young Age and Crime in Society: A Study on Youth Prisoners in Bangladesh
}

\author{
Israt Eshita Haque $^{1}$, Mehjabin Haque ${ }^{2}$, Md. Muniruzzaman ${ }^{1}$ \\ ${ }^{1}$ Department of Sociology, Noakhali Science and Technology University, Nokhali, Bangladesh \\ ${ }^{2}$ BSS and MSS in Sociology, University of Dhaka, Dhaka, Bangladesh \\ Correspondence: Md. Muniruzzaman, Department of Sociology, Noakhali Science and Technology University, Nokhali, \\ Bangladesh.
}

Received: March 23, 2020

Accepted: April 20, $2020 \quad$ Available online: April 23, 2020

doi:10.11114/ijsss.v8i3.4779

URL: https://doi.org/10.11114/ijsss.v8i3.4779

\begin{abstract}
In a given society, crime is a social phenomenon and an inconsistent act of social order. Engagement of young boys and girls in diverse criminal activities is becoming a universal and more complicated issue in human society. The involvement of youths in different types of crimes is also becoming a major concern in Bangladesh. Hence, this study aimed to investigate the factors influencing the young prisoners in the involvement of various criminal activities. The major theoretical perspectives of criminology, including Strain Theory, Differential Association Theory, Social Disorganization Theory, and Labeling Theory, were used to provide explanations for causes of criminal behavior among young prisoners. The study was conducted employing a mixed approach, that is, taking into consideration both quantitative and qualitative methods because of its nature and subject matter. A survey was carried out by using a structured questionnaire. Moreover, in-depth interviews were carried out to have a deeper understanding of the phenomena under study. The study found that while problematic family relationship and family crisis is the main driving factor influencing the young prisoners for committing the crime, other factors including the influence of neighborhood, peers, poverty, media and social reaction towards individual have also played an influential role.
\end{abstract}

Keywords: young age, crime, prisoners, poverty, peer group

\section{Introduction}

Youths are the most essential part of society. The horrifyingly vertical rise of juvenile crimes in recent years has turned into an issue of serious concern for the parents as well as the community all over the world. In a word, our innocent young boys and girls have become mentally and psychologically restless and impatient as a direct result of an endless uncertainty and insecurity that is engulfing them from all corners (Hasan, 2018). According to the FBI statistics, most crimes are committed by adolescents. Generally adolescence is a time of heightened vulnerability and we have to rethink adolescence as adolescence itself is changing. Nowadays adolescence begins much earlier, and it ends much later (Steinberg, 2015). In Bangladesh the involvement of adolescents and youths in criminal activities is really very alarming. Academicians and human rights activists said that unemployed youths and those dropped out of schools or colleges were mainly involved in the gangs and commit criminal activities due to lack of recreational activities, social degradation, weakening roles of the family, unlimited access to internet, lack of moral lessons in the family and the school (Das, 2019). In this study youth prisoners (aged 15 to 29) were selected as they represented more adequately to find out the research objectives.

The numbers of juvenile delinquents are increasing in Bangladesh; the rate is alarming in Dhaka city. One responsible source of police claimed that $40 \%$ of the arrested criminals are young. They are involved in theft, robbery, hijacking, and extortion, and they possess different types of deadly weapons, including firearms. They are even committed in killing (Karzon, 2008). As Bangladesh observes National Child Rights Week 2016 from September 29 to October 5, sources at the Ministry of Home Affairs say around 44\% of the street children in the country are involved in drug peddling, 35\% are engaged in picketing, $12 \%$ in mugging, $11 \%$ in human trafficking and $21 \%$ in other criminal activities (Khan \& Tipu, 2016). Now the academicians and researchers should come forward to investigate why the adolescents and youths are being involved in criminal activities. 
There are links between a specific sub-type of family violence and involvement in youth offending, for example, between youth offending and experiencing: sibling violence, violence against women and girls (VAWG), childhood physical abuse, child to parent violence and witnessing domestic violence (Consulting \& Bright, 2018). Again frequent quarrels among parents, undue domination of one over the other, step-motherly treatment with children, successive births in the family, immorality of parents, misery, poverty or unwholesome family atmosphere and the like may also lead to the neglect of child and findings no adequate outlet for his talents; he may tend to become criminal in his life (Mia, 2019). There is also empirical evidence indicating that social environment, upbringing factors, poverty, disadvantaged neighborhoods, and sex differences contribute to criminality in different ways (Mundia, Matzin, Mahalle, Hamid, \& Osman, 2016). Juvenile delinquency is now a primary concern all over the country. Children are the most desired resource for our future; they are the lights which will remove all darkness from the society and work for a better world. But, it is a matter of great regret that juvenile delinquency is flourishing alarmingly (Majbahin, 2017).

This study aims to investigate the factors influencing the young prisoners in the involvement of various criminal activities. The study tries to examine the relationship between the problematic family relationship pattern, family crisis, neighborhood impact, peer group impact, poverty, media, and social reaction towards individuals and crime of young prisoners.

The major theoretical perspectives of criminology, including Strain Theory, Differential Association Theory, Social Disorganization Theory, and Labeling Theory, have been applied to provide explanations for causes of criminal behavior among young prisoners. This study seeks to make a relationship between young age and crime in Bangladesh society. This study also tries to find out the pattern and trends of recent young age crime in Bangladesh. Finally, this research also provides a discussion of policy recommendations to reduce crime among young ages and strategies to develop young ages as a prosperous future for society.

\section{Research Objectives}

To conduct this research it was found that there are several dimensions that are required to be explored to understand the overall scenario of the crime among the young age group in Bangladesh society. Henceforth, the main objective of the study is to explore the relationship between young age and criminal activities. A line of the broad purpose, this study will depend on the following number of specific goals which are:

1. To identify the key factors that stimuli the young age to commit crime;

2. To explore the pattern and trends of recent young age crime in Bangladesh;

3. To propose a list of recommendations based on the respondents' comments and findings of the research.

\section{Methodology}

Both quantitative and qualitative methods have been employed in this study because of its nature and subject matter. This study was conducted between the periods of December 2018 to June 2019. In this study, the research site was Jamalpur District Jail that was selected by implementing the purposive sampling method. Young prisoners groups (aged 15 to 29) had been selected because they would be more enthusiasts and more representatives to give answers to find out the research objectives.

In a quantitative study, a survey was carried out as the primary data collection instrument by using a structured questionnaire. In this study, 80 respondents were sampled who were prisoners at Jamalpur district jail and directly involved in criminal activities. All the respondents were male as there was no any female prisoners at Jamalpur District Jail during the time of data collection. There were some female respondents who were shifted to Sherpur District Jail (A nearby district of Jamalpur) due to infrastructural problem before conducting this research. It's indeed a limitation of this study. The respondents were selected purposively due to the convenience of the researchers. In this research, the data has been analyzed in terms of a frequency distribution by employing descriptive statistics.

Furthermore, because of the sensitivity and complicated issue of young age crime, the qualitative research method was also used to get a complete picture of this study. As a qualitative method, in-depth interviews were carried out by semi-structured interview schedules to have a deeper understanding of the phenomena under study. Five case studies have been documented for cross-checking the quantitative data and prepare this research well representative one. Data had been collected from secondary sources (journals, articles, books, reports unpublished research materials, dissertation, etc.) to supplement the primary data. Description and explanation of themes and concepts are presented in a narrative way to seek the answers to the research objectives. In the time of conducting research, ethical issues voluntary participation, consent of the respondents, right to privacy, etc. had been considered consciously.

\section{Theoretical Orientation of Crime}

A large number of theories have been proposed in the context of an explanation of the causation of crime in society. There are some biological, psychological, economic, and sociological explanations of crime. All of these theories differ 
from one another to explain the causation of criminal behavior among people. In this study, four major sociological theories have been focused to explain the relationship between the young age group and crime in society. This study stated that the engagement of young age boys and girls in different types of crime as well as intending to commit a crime does not happen only one cause. Furthermore, there are many influencing factors includes family relationship patterns, the impact of a broken family, financial conditions, the impact of mass media, social interaction pattern, neighborhood, and peer group responsible for committing criminal behavior. The major theoretical perspectives of criminology, including Strain Theory, Differential Association Theory, Social Disorganization Theory, and Labeling Theory, have been used in this study to provide explanations for causes of criminal behavior among young prisoners.

Table 1. Summary of Theoretical Arguments

\begin{tabular}{ll}
\hline $\begin{array}{l}\text { Theories } \\
\text { Strain Theory } \\
\text { Theorists: Merton, Messner, Rosenfeld, Davis and Runciman. } \\
\text { (Adler, Mueller, \& S.Laufer, 1991) }\end{array}$ & $\begin{array}{l}\text { Key Arguments } \\
\text { Disparity between goals and means fosters frustration which } \\
\text { leads to stain } \\
\text { Strain creates pressures and incentives to engage in criminal } \\
\text { activities }\end{array}$ \\
$\begin{array}{l}\text { Explain why individual intends to deviant behavior } \\
\text { Theorists: Edwin H. Sutherland and Donald Cresse (Kader \& } \\
\text { Hussain, 2017) }\end{array}$ & $\begin{array}{l}\text { Explain deviance in terms of individual's social relationships } \\
\text { Criminal behavior is learned through social interaction with } \\
\text { other deviant behavior }\end{array}$ \\
$\begin{array}{l}\text { Social Disorganization Theory } \\
\text { Theorists: Robert E. Park and Ernest Burgess, W.I Thomas and }\end{array}$ \\
$\begin{array}{l}\text { Florian Znaniecki. (Adler, Mueller, \& S.Laufer, 1991) } \\
\text { social bonds, family and neighborhood associations, and social } \\
\text { controls in communities. } \\
\text { Crime is said to be more likely in communities that are } \\
\text { economically deprived. }\end{array}$ \\
$\begin{array}{l}\text { Labeling Theory } \\
\text { Theorists: Howard Becker, Edwin Lemert. (Adler, Mueller, \& stigmatizing a person by the label as criminal } \\
\text { Individuals who are arrested, prosecuted, and punished are } \\
\text { S.Laufer, 1991), (Kader \& Hussain, 2017). }\end{array}$ \\
$\begin{array}{l}\text { labeled as criminals. } \\
\text { Deviant is one to whom that label has successfully been applied. } \\
\text { A dominant Western theory in the literature on fear of crime is } \\
\text { vulnerability theory, which typically uses socio-demographic } \\
\text { characteristics as indicators of the vulnerability of individuals. }\end{array}$ \\
\hline $\begin{array}{l}\text { Vulnerability Theory } \\
\text { (Liu, F. Messner, Zhang, \& Zhuo, 2009). }\end{array}$
\end{tabular}

(Source: Authors)

Table 1 shows the major theories of crime explained by prominent sociologists and criminologists with their key arguments. Some of the arguments are closely associated with this study. In the following sections, these theoretical understanding and concepts are discussed and connected to understand the causation of involving different criminal activities among the young age group in Bangladesh.

\section{Result and Discussion}

\subsection{Socio-Demographic Profile of the Respondents and Crime in Society}

The information of the participants was constructed by the researchers from the prisoners (aged 15-29) of Jamalpur district jail. Socio-demographic data were collected concerning a wide range of categorical variables included: the participants' age, education, marital status, occupational status, living area of the respondents, types of crime committed, number of times the same crime was repeatedly committed, and the reasons for committing the different crimes among the young prisoners.

The socio-economic status of the childhood household influences the risk of developing illegal drug problems later in life. School failure and childhood socio-economic status predict illicit drug abuse independently in youth and young adults in Sweden (Gauffin, Vinnerljung, Fridell, Hesse, \& Hjern, 2013). However, in the case of interviewing, the information of the respondents was collected extensively to analyze the in-depth situation of the socio-economic status of respondents that will help to link the young age group and crime in society. 
Table 2. Socio-Demographic Status of the Respondents

\begin{tabular}{llll}
\hline Age Distribution & Age group & Frequency & Percent \\
\cline { 2 - 4 } Educational Level & $15-19$ & 11 & 13.75 \\
& $20-24$ & 47 & 58.75 \\
& $25-29$ & 22 & 27.5 \\
& Education & Frequency & Percent \\
& Illiterate & 20 & 25 \\
& Primary & 18 & 22.5 \\
& Secondary & 16 & 20 \\
Occupational status & Higher Secondary & 16 & 20 \\
& Degree/ Hon's level & 10 & 12.5 \\
& Occupation & Frequency & Percent \\
& Businessmen & 32 & 40 \\
& Industrial worker & 18 & 22.5 \\
Marital Status & Student/Unemployed & 17 & 21.25 \\
& Private Worker & 7 & 8.75 \\
& Government Worker & 6 & 7.5 \\
Living Area & Marital Status & Frequency & Percent \\
& Married & 32 & 40 \\
& Unmarried & 48 & 60 \\
\hline
\end{tabular}

(Source: Authors, Field Survey)

In table 2, the age distribution, with five years interval, of respondents, shows that more than half of the respondents belong the age group between 20-24 years, and they are about 58\%; about $27 \%$ are in the age group 25-29 years and the rest of them are aged between 15-19 years. Such distribution is considered to create a more representative basis for the present study.

There is a notable variation in the education level among the sample respondents selected for the study. This study shows that about $25 \%$ of the respondents are illiterate, and about $22 \%$ of respondents have completed primary education. One-fifth of the respondents completed secondary school, and another one fifth completed higher secondary education, and very few completed graduation. Three-fourths of the respondents are illiterate, and more than $12 \%$ of them received a tertiary level of education. Criminal behavior in adolescence can have strong links to future adverse outcomes, among them adult crime, low academic performance, and early school leaving. At the same time, school dropouts can encourage juveniles to become involved in criminal behavior (Rud, Klaveren, Groot, \& Brink, 2013). This study shows that there is a positive correlation between education and crime. Low educated people are more prone to commit crimes compared to a highly educated people. Moreover, highly trained people have also committed the crime because of their adverse family circumstances.

Remarkable diversity has also found in the occupational variations of the respondents. As the table depicts - half of the respondents( about 40\%) were associated with business, less than one-third were worked as industrial worker (about $22 \%$ ) and about $21 \%$ were students. Some respondents completed their study but did not get any job. They were also included in this category. Only $8 \%$ were private workers and rest $7 \%$ were government workers. Among all these respondents some were unemployed for a certain period of time after completing study or drop out from educational institutions. Later they joined in some income generating activities as small businessmen and workers in some factories/industries. This study also depicts that living area is an important indicator to commit the crime. The most exciting findings are that 50\% of prisoners are from an urban area, and 50\% of prisoners are from a rural area. Therefore, prisoners both from urban and rural areas committed different crimes for a different points of view and unusual circumstances. Ecological aspects of crime can best be demonstrated by an analysis of a variety of crimes operating in urban as well as rural areas. The incidence of Juvenile delinquency, shoplifting, petty theft, and sexual offenses are common in slum areas and poverty-stricken homes. That apart, the recurrence of white- collar crimes, bank offences, frauds, embezzlement, racketeering, and the like are mostly confined to the urban regions (Mia, 2019). This study shows that the incidence of the drug business, theft, robbery, murder, and sexual offenses are common in rural areas and poverty-stricken homes. That apart, the occurrence of corruption, smuggling, drug business, eve-teasing, trafficking and prostitution, threat and coercion, burning car, etc. are mostly confined to the urban regions.

In this study, a descriptive survey result suggests that the levels of offending tend to be lower among married prisoners. This study shows that $40 \%$ of married respondents are prisoners who are less likely to involve with criminal activities compared to $60 \%$ unmarried prisoners. However, married inmates (20 persons) stole more than their unmarried 
counterparts (18 people).

\subsection{Different Types of Crime by Age Group}

The relationship between age and crime is one of the most solid within the field of criminology. It is understood that crime increases throughout adolescence and then peaks at age 17 (slightly earlier for property crime than for violent crime) and then begins to decrease over the life course moving forward (Cornelius, J. Lynch, \& Gore, 2017). Kanazawa and Still expanded the boundaries of crime-prone young ages further, by saying: "The proportion of young men 15-34 strongly predicts that the incidence of murder, rape, assault, and robbery across all societies of the world" (Kanazawa \& Still, 2002).

Table 3. Types of crime by age group

\begin{tabular}{|c|c|c|c|c|c|}
\hline $\begin{array}{l}\text { Type of } \\
\text { Crime }\end{array}$ & $\begin{array}{l}\text { Aged15-19 } \\
\text { Years }\end{array}$ & $\begin{array}{ll}\text { Aged } & 20-24 \\
\text { Years } & \\
\end{array}$ & $\begin{array}{ll}\text { Aged } & 25-29 \\
\text { Years } & \end{array}$ & Frequency & Percent $(\%)$ \\
\hline Theft & 3 & 13 & 5 & 21 & 26.25 \\
\hline Robbery & 2 & 2 & 1 & 5 & 6.25 \\
\hline Drug Offences/Trade & 9 & 8 & 2 & 19 & 23.75 \\
\hline Rape, Eve-teasing & 3 & 3 & 1 & 7 & 8.75 \\
\hline Smuggling & 0 & 0 & 2 & 2 & 2.5 \\
\hline $\begin{array}{l}\text { Female trafficking and } \\
\text { prostitution }\end{array}$ & 1 & 3 & 1 & 5 & 6.25 \\
\hline Threat and coercion & 2 & 6 & 2 & 10 & 12.5 \\
\hline Murder & 0 & 1 & 2 & 3 & 3.75 \\
\hline Burning Car/ Arson & 1 & 3 & 1 & 5 & 6.25 \\
\hline Corruption & 0 & 1 & 2 & 3 & 3.75 \\
\hline
\end{tabular}

Source: Author, Field Survey

In this study, sample has been divided into three categories of young ages, and these are 15-19 years age group, 20-24 years age group, and 25-29 years age group (Table-3). Participants aged 20-24 years committed the highest number of crimes. However, the younger prisoners (age range 20-24 years) committed more crimes compared to the age group 25-29 years. On the other hand, the age group between 20-24 years committed more crimes compared to the age group between 15-19 years as well.

An analysis of the type of crimes perpetrated revealed that all groups (15-19 years, 20-24 years, and 25-29 years) were high on stealing (theft) and drug offenses. There were variations of crimes included: stealing, robbery, drug offenses, rape, eve-teasing, smuggling, female trafficking, prostitution, threat and coercion, murder, burning car, arson, and corruption in terms of different age group. The cyber-crime committed with the help of information technology, has also been found among the young generation that is not documented in the table.

On the other hand, younger prisoners aged 15-19 years and aged 20-24 years were more into drug offenses, theft, burning car giving threat and coercion than aged 25-29 years those were more into smuggling, corruption, murder, etc. Meanwhile, according to children's rights watchdog Bangladesh Shishu Adhikar Forum (BSAF), 18 children aged between 12 and 17 years were arrested while carrying firearms, 5 in the same age range for murder, 6 for drug peddling, 26 for rape, 18 for robbery and theft and 33 for participating in political violence in 2015. Besides, 14 children aged between 12 and 17 years were convicted of sexual harassment by mobile courts (Khan \& Tipu, 2016). Therefore, there is a strong correlation between different types of crimes and different age groups in this study.

\subsection{Family Relationship Pattern and Young Age Crime}

This study tried to find out the relationship between family circumstance and their relationship pattern with criminal activities among young ages. This study emphasized to find out family relationship patterns, family disruption, family crisis, and overall family structure and how they may contribute to adolescent and young adult criminal behavior. Paternal crime, descriptions of the families' patterns of stability, and socioeconomic status changes over the life of the offspring determine their association with official records of adolescent and young adult crime (Mednick, Baker, \& Carothers, 1990). This study emphasized some characteristics of the family include types of family, marital relationship patterns, quarreling with family, domestic violence in the family that may contribute to involve criminal behaviors. 
Table 4. Family Relationship pattern and Young age Crime

\begin{tabular}{llll}
\hline \multirow{2}{*}{ Type of Family } & Family Type & Frequency (N-80) & Percent $(\%)$ \\
\cline { 2 - 4 } & Joint & 12 & 15 \\
Conjugal Relationship in & Nuclear & 68 & 85 \\
Family & Conjugal Relationship & Frequency (N-32) & Percent $(\%)$ \\
& Happy & 18 & 56 \\
Quarrelling with & Unhappy & 14 & 44 \\
Partner & Quarrelling & Frequency (N-32) & Percent (\%) \\
& Yes & 26 & 81 \\
Domestic Violence & No & 6 & 19 \\
& Domestic Violence & Frequency (N-32) & Percent $(\%)$ \\
\hline
\end{tabular}

(Source: Authors, Field Survey)

Table 4 shows that $85 \%$ of the respondents were from nuclear family, and other $15 \%$ were from joint family. $40 \%$ of respondents were married in this research and the number of married respondents were 32 . This $40 \%$ told their own experiences, and the other $60 \%$ shared their relationship patterns with their parents and other family members. $56 \%$ of the married respondents said that they were happy in their conjugal life and $44 \%$ of the respondents mentioned that they were unhappy in their conjugal life. About $81 \%$ of the respondents experienced quarreling environment in the family. Only $19 \%$ mentioned that they did not quarrel with each other in the family. About $56 \%$ of respondents shared that domestic violence was existed in their family and other $44 \%$ said that there was no domestic violence in their family.

Other unmarried respondents mentioned that they had experience of bad relationships, quarrel and chaos with family members which pushed them to mix with bad group of people.

Many children struggle to cope with the challenges they experience. Facing continuous family violence and without recourse to adequate help when they need it. It is known that some young people go on to be involved in the youth justice system. The evidence shows that the more risk factors, for example, adverse childhood experiences (ACEs) experienced by young people, the higher the likelihood of participation in youth offending (Consulting \& Bright, 2018). The empirical evidence shows that too many young men and women from broken families tend to have a much weaker sense of connection with their neighborhood and are prone to exploit its members to satisfy their unmet needs or desires. This contributes to a loss of a sense of community and the disintegration of neighborhoods into social chaos and violent crime (Chesterton, 2020).

The problematic family constitutes a principle cause for the deviation of the juvenile. Absence of father or mother due to death and divorce, lack of parental control, lack of home discipline, bad relation between father and mother, presence of criminal among the members of the family are the principal indications of the problematic family (Rahman, 2008). Due to the weakening of the bond of love within family members, violence is increasing within families, even killings. On 28 February, 2018, a youth was killed by his father and brother in Azimpur, Dhaka. Similarly, the rate of rape is increasing in Bangladesh because families failed to teach social norms and ethical values to their members (Rezvi, 2018). The present study also tries to show how family crisis accelerate crimes.

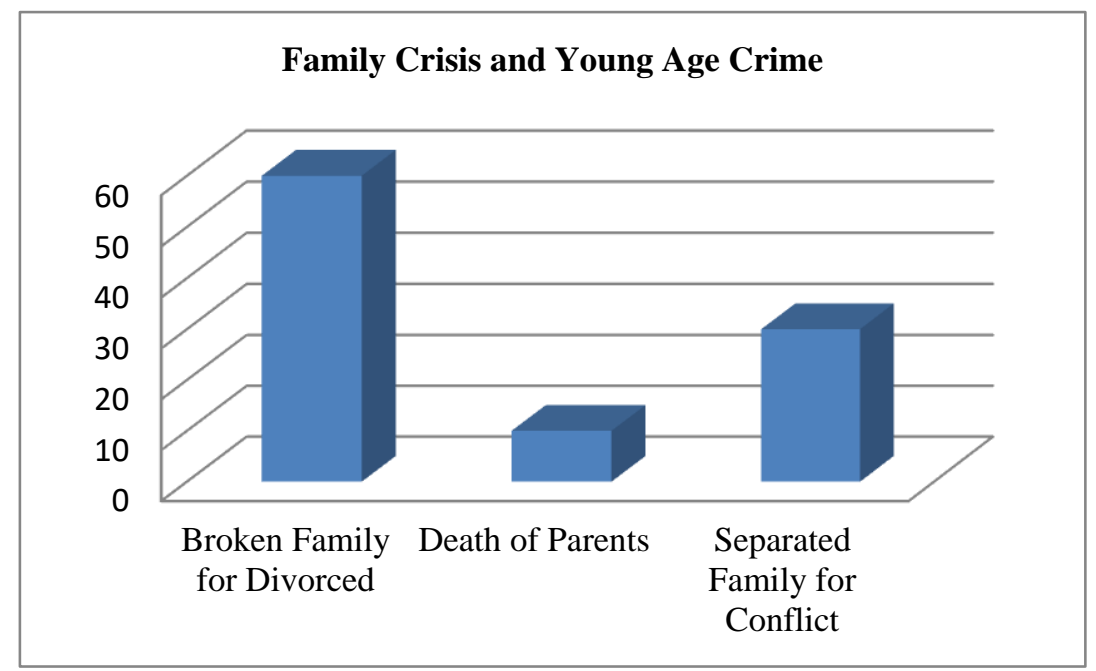

Figure 1. Family crisis and Young Age Crime (Source: Authors) 
In this study, to find out the relationship between family crisis and crime among young ages, the family has been divided into three categories. One is a broken family for divorce, another one is death of parent/s and the rest is separated family for conflict. Figure 1 shows that about $60 \%$ respondents seemed that young ages from the broken family for divorce are more committed to different types of crime compared to the death of parent/s. About $30 \%$ of respondents seemed that separated family for internal conflict influences adulthood and youth in badly. This influence may lead the young people to behave abnormally and commit crimes such as drug-addiction, suicidal tendencies, acting with his/her family members just the same as his/her parents do. One of the respondents named Zakir shared his experience ${ }^{\mathrm{i}}$.

According to the researchers, 'juvenile delinquency' is positively co-related to 'family separation.' The more family separation occurs in a society; the more juvenile delinquency will be there. In this urbanization era, the idea of the extended family has been eradicated, and thus, there is a lack of intimacy or bonding in most of the families. Moreover, families are breaking apart. A child from a broken family does not grow with proper care, and education which leads the child to an unrest future (Majbahin, 2017).

Labeling theory can be applied to this study. This theory states that once young people have been labeled as criminal, they are more likely to offend. Labeling theory says that male children from low-income families are more likely to be labeled deviant, and that this may particularly explain why there are more lower-class young male offenders (Mia, 2019). Labeling theory declares that the reaction of other people and the subsequent effects of those reactions create deviance (Adler, Mueller, \& S.Laufer, 1991). This study shows that young ages like 'Zakir' further involved in anti-social and anti-law criminal behavior because of the negative attitude towards them who are punished for the crime. Sutherland holds that out of all the social processes, the family background has perhaps the most considerable influence on the criminal behavior of the offender, the reason being that children spend most of their time with their parents and relatives within the family. Children are apt to imbibe criminal tendencies, if they find their parents or members of the family behaving in a similar manner (Sutherland, 1947).

\subsection{Financial Condition and Crime in Society}

This study stated that there is the strong relationship between financial crisis and crime in society. Economic crisis because of unemployment, poverty, river erosion, low standard of living, the environmental hazard is linked to criminal behavior. The relationship between economic crisis and crime could be exemplified by applying strain theory of criminology. Lower-class individuals more often experience strain, with this strain being a function of the disjunction between their goals and the legitimate means for achieving them. Merton states that there are several ways to cope with this strain, some of which involve crime. Individuals may attempt to achieve monetary success through illegitimate channels, such as theft, drug selling, and prostitution (Jang \& Agnew, 2015).

Strain theory states that crime is the natural result of the convergence of a few concepts;

First, our society imparts on the individual a need to obtain success to achieve status,

$>$ Second, the legitimate means of achieving that success are limited,

$>$ Third, those who are unable to reach that success in a lawful manner will resort to crime to keep status or as a means of objecting to the system (Agnew, 1992).

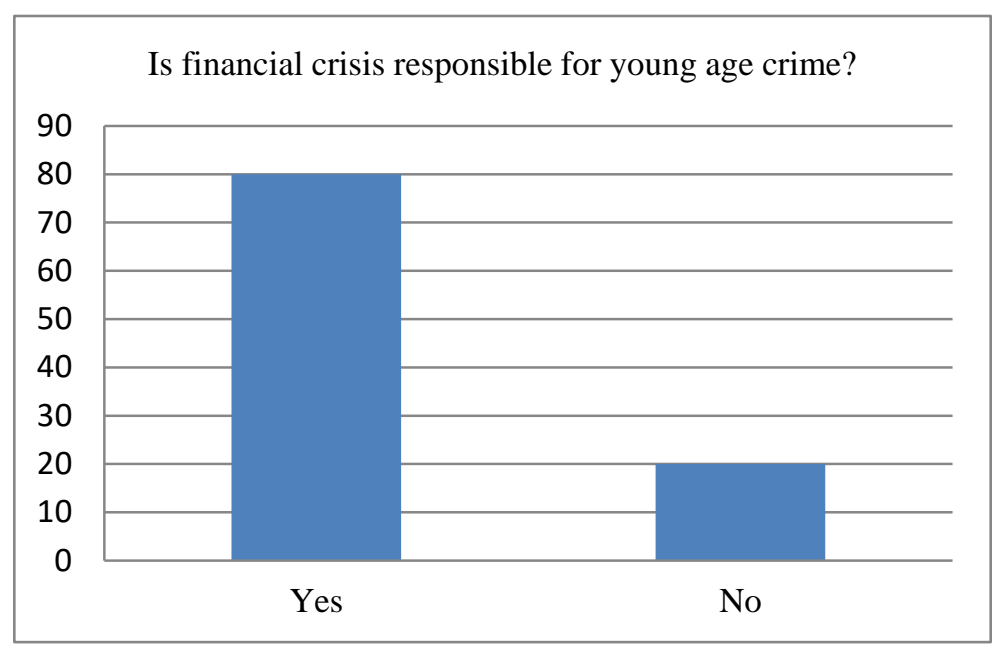

Figure 2. Is financial crisis responsible for young age crime? (Source: Authors) 
A large number of people in Bangladesh have to struggle against poverty, some of them are involving with criminal activities to fulfill their basic needs. Sometimes they have to choose criminal activities as the strategy for escaping from poverty (Haque \& Muniruzzaman, 2020). Figure 2 shows that about $80 \%$ of the respondents said that they were involved in criminal activities due to financial crisis. Due to poverty, they feel stains to achieve their required goal, and they try to gain their goal by involving different criminal activities. On the other hand, another $20 \%$ of respondents seemed that media creates individualism, anomie, and also a cultural change that would be responsible for committing different crimes among the youths. In this study one of the respondents named Rubel shared his similar kind of experience $\mathrm{i}^{\mathrm{ii}}$.

In Bangladesh, millions of families are living in the slums or often on the streets. So, a child who has grown up in such unfortunate situation, life is street centered for them, not home-centered, which breeds demoralization and apathy. To find an escape from this horrible life, many adolescents and youths choose the wrong path and involve in criminal activities (Majbahin, 2017).

\subsection{Neighborhoods and Surrounding Environment' and Their Impact on Crime}

The background of the neighborhood in which an individual grows up has a significant impact on one's personality development both in negatively and positively (MacDonald, et al., 2009). It has also impact on the number of problem behaviors he or she displays during his or her whole lifetime. This study wanted to connect the relationship between the impacts of neighborhood environment and involving different criminal activities among young age. The surrounding environment of the slum area, smuggling zone, and crime are very vulnerable for juveniles. When residing in such regions, youths come in contract with criminal patterns and learn illegal techniques, and then they become notorious criminals (Kader \& Hussain, 2017). In this study, one of the respondents named Jamal mentioned that neighborhoods and surrounding environment have influence to get involve with criminal activities ${ }^{\text {iii }}$.

According to the social disorganization framework, such phenomena are triggered by the weakened social integration of neighborhoods because of the absence of self-regulatory mechanisms, which in turn are due to the impact of structural factors on social interactions or the presence of delinquent subcultures. Poor neighborhoods and the emergence of group behavior linked to criminality (Rengifo, 2017).

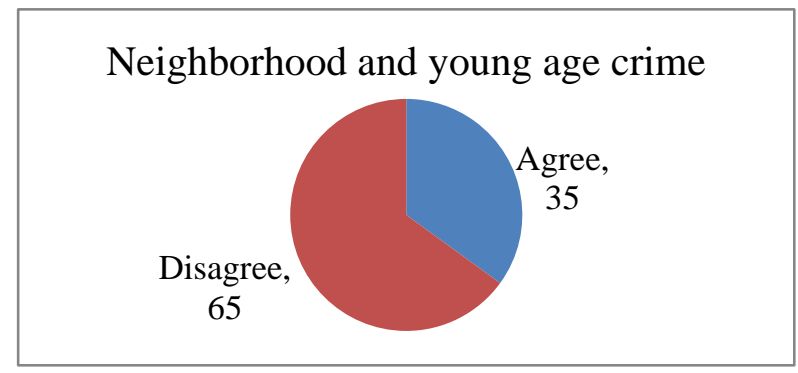

Figure 3. Neighborhood and young age crime (Source: Authors)

In this study, figure 3 shows that only $35 \%$ of the respondents seemed that there is the relationship between neighborhood and crime among young age. On the other hand, about $65 \%$ of the respondents didn't agree with the relationship between neighborhood influence and criminal behavior among the young age group.

Rapid changes in industrialization or urbanization increased immigration which leads to the decline of the effectiveness of institutional and informal forces in communities and neighborhoods. This process is also considered as social disorganization which is responsible for rising delinquency or youthful crimes in specific areas or neighborhoods (Shoemaker, 2018). However, neighborhood influences also have much to do with the nature of crimes in a particular locality. Thus, thickly inhabited areas, town, and cities offer frequent opportunities for sex offenses and crimes relating to theft, bootlegging, burglary, kidnapping, cheating, and deceit, and so on. Some anti-social institutions such as prostitution houses, gambling dens, brothels, and similar other dubious institutions rise in these areas (Mia, 2019).

\subsection{Peer Group and Influence on Crime among Young Age}

This study tried to explain the relationship between peer group and criminal behavior among young individuals. Sutherland's differential association theory is appropriate to describe this relationship. The idea that criminality is learned is entirely appropriate in contrasting a model of how one age out of offense (Cornelius, J. Lynch, \& Gore, 2017). Sutherland suggests that the individual does not spontaneously commit a crime, but rather, learns the skills needed to 
commit crimes from one's peers and also learns through their established peer network that continued criminality, via a set of cultural standards, is acceptable (Sutherland, 1947). In Sutherland's theory, the current study finds a foundation of peer support for criminality. Close friendships among wider peer groups can influence adolescents' involvement with criminal activities as wider group of peers or classmates may affect adolescents' attitudes and behavior ( Kim \& Fletcher, 2018). The present study also finds that peer groups influence the adolescents and youths to get involve with criminal activities.

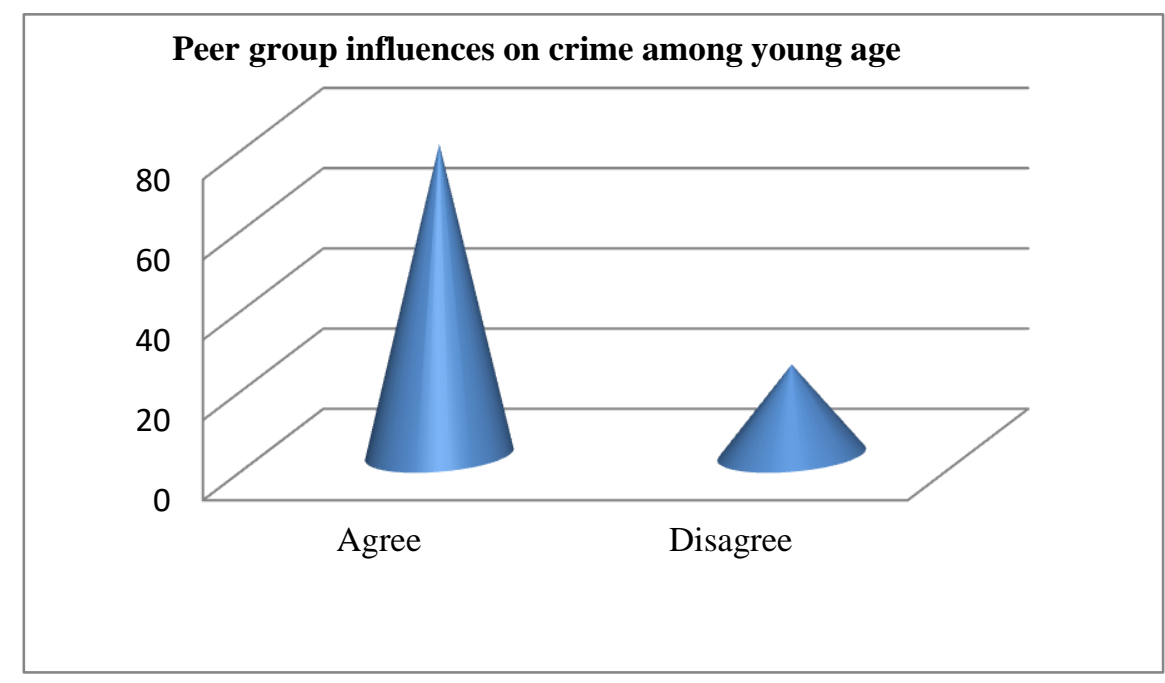

Figure 5. Peer group influences on crime among young age (Source: Authors)

Figure 5 shows that about $77 \%$ of respondents said that peer group influenced them to involve in criminal activities. On the other hand, only $22 \%$ disagreed with this argument. They seemed that young age people commit a crime not for peers influence; instead, they were involved in crime for their low income, social inequality, family pressure. One of the respondents named Ridoy shared his experience ${ }^{\mathrm{iv}}$

According to the theory of Differential association, young people in a group context and looks at how peer pressure and the existence of gangs could lead them into a crime. It suggests young people are motivated to commit crimes by delinquent peers, and learn criminal skills from them (Mia, 2019). Peer pressure becomes the most substantial influence on adolescents in terms of drug use, alcohol use, cigarette smoking, prostitution, involvement in cultist examination malpractice, violence, and other criminal activities in secondary and tertiary institutions (Esiri, 2016).

\subsection{Impact of Mass Media on Young Age Crime}

This study tried to correlate the relationship between media and crime among young ages. Numerous scientific researchers found that mass media (television in mainly) offers a lifestyle through which the universe approaches the human, making the act of reading and thinking superfluous, in other words, it has a reduced pedagogical value by flattening passions, by identifying well-being with happiness (Dr. Gabriela Iorgulescu, 2018). Many researchers have concluded that young people who watch violence tend to behave more aggressively or violently, particularly when provoked (Kader \& Hussain, 2017). Media bring an individual to violence in three ways.

$>$ First, movies that demonstrate violent acts excite spectators; the aggressive energy can then be transferred to everyday life,

$>$ Second, television can portray ordinary daily violence committed by parents or peers.

Third, the violence depicted in the media is unreal and has a surrealistic quality. (Mia, 2019) 


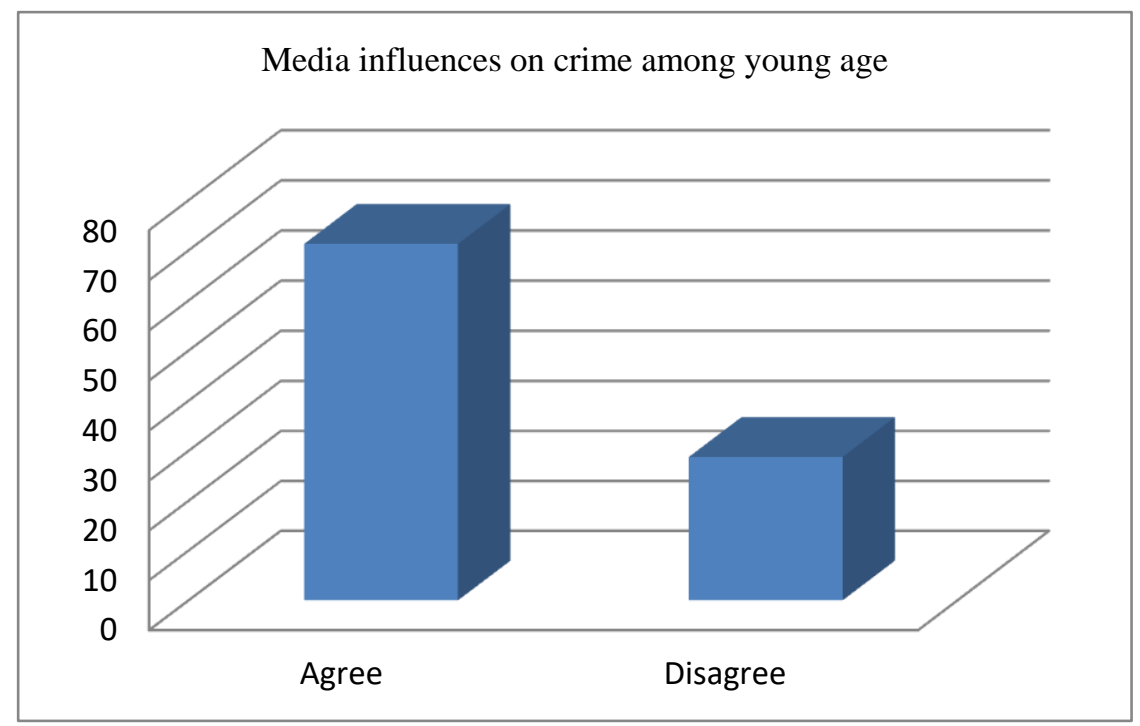

Figure 6. Media influences on crime among young age (Source: Authors)

This study indicated interesting findings that only $28 \%$ of respondents agreed with this statement that media influences criminal behavior among the young age groups. On the other hand, $71 \%$ of respondents didn't agree with the explanation of the relationship between media and crime among young ages.

One of the respondents 'Rifat' shared his experience of mobile phone addiction and involvement with crime. ${ }^{\mathrm{V}}$ Another respondent named 'Rasel' mentioned that he was influenced by TV serial to get involve with crime. ${ }^{\mathrm{vi}}$

The juvenile or adolescent population is greatly influenced by the internet. Crime films, yellow literature, pornography, or blue films are available on the internets that are a threat to a child's development. Various means of entertainment, sometimes, convey messages which put the children into a dilemma because of the differences in cultural values (Majbahin, 2017). Action movies and satellites have a negative impact on the mindset of young boys and girls. The violence and sex depicted in the film incite juveniles to go brothel and to commit unauthorized activities (Karzon, 2008).

\section{Recommendations and the Further Implication}

The researchers have proposed some recommendations and further suggestions of this research study. These recommendations and further implications may help to reduce criminal behavior among young ages. The researchers observed that problematic family in terms of relationship patterns and family crisis is the main driving factor influencing the young prisoners for committing the crime.

At present, even the nuclear family structure is also vulnerable in western countries. They are having increased families of single fathers and single mothers. As a consequence, families are failing to teach about ethics, values, and norms to the members. As a result, the kinship of family, and bonding of society are becoming weaker day by day and also unethical, and unsocial activities like crimes, violence and eve-teasing, etc. are increasing in society (Rezvi, 2018). The parents and teachers should be more careful of the children so that they cannot get any chance to commit the crime (Rahman, 2008). This study shows that other factors, including the influence of neighborhood, peers, poverty, media, and social reaction towards individuals have also played an influential role.

This study seeks the way out to help the young prisoners not involving again in different criminal activities. This research result suggested some strategies that can be applied for the further implication of preventing crime in society:

$>$ This research study suggests that the families should be re-established in its original primary position (Joint Family) by learning all individual, social, and national values and norms that would help to control young age's crime in society.

$>$ There is also needed to build a strong relationship among members in society.

$>$ Neighborhoods should interact with young prisoners after returning from being punished and council them instead of only blaming them. 
$>$ This study has been noted that the peer group is a crucial contributor to involve criminal activities among young ages in society. Therefore, this study suggests that peer group should allow maintaining a relationship with his/her friends when he/she will come back from correctional institutes and jail.

> Parents should be careful and concerned about their children's friends.

$>$ The social reaction towards offenders should be positive and with sympathy and allow them to express his or her feelings.

$>$ This study also suggests that to alleviate poverty can lead the young ages with a peaceful and standard life. Because poverty is also playing vital factor in involving different anti-social behavior like crime among young generations.

$>$ The educational institutions could be an essential tool to prevent criminal behavior and unlawful attitudes spatially among children and youth.

> Media should be more concerned about broadcasting different programs that may influence young boys and girls to involve various criminal activities.

$>$ Proper steps should be taken by the government and correctional institutions in this regard.

To prevent young age crime, it is essential to know what types of crimes have been committed by young prisoners in recent time. This study also tries to show that the trend and pattern of young age crime in Bangladesh that would be helpful to reduce the young crime rate. Furthermore, this study addressed the causes of young age crime in society. These research findings can help government, non- government organizations and agencies, local housing policy, community investment decisions by giving information about the young age crime scenario in Bangladesh.

The rise of juvenile delinquency in Bangladesh is hindering the development of the country. It is high time the government needed to put more emphasis on this issue as the future of our country rests in today's children. For maintaining a sustainable development for our country, it's necessary to keep our children as one of the core concerns of the State. Only then, we will be able to move one step closer to the apex of progress (Majbahin, 2017). Bangladesh has no comprehensive juvenile justice system for dealing with children in conflict with the law (Kader \& Hussain, 2017). As the involvement in different criminal activities among young ages is influenced by a variety of factors, prevention effort should be comprehensive. This research hopes that after taking consideration of the research result of this study and all these above- mentioned recommendations and strategies, further research can also be conducted to find out the implementation policy of these recommendations and strategies that also could be helpful to reduce young age crime in Bangladesh society.

\section{Summary of the Findings}

After a brief overview of the relationship between young age and crime in Bangladesh society, it can be concluded that changing family and unstable circumstances of family and other family crisis especially divorce are more prone to involve criminal activities among young ages. The respondents' socio-demographic profile, different types of crime by age group, family relationship pattern and family crisis, mass media, financial condition, neighborhoods, the peer can influence young ages to commit different types of crimes in society. The patterns and level of crimes are various along with the context of respondents' age, educational and occupational backgrounds, marital status, living area, etc. The major theoretical perspectives of criminology, including Strain Theory, Differential Association Theory, Social Disorganized Theory, and Labeling Theory, had been applied in this study to provide explanations for causes of criminal behavior among young prisoners. In this study, the theories are related and more appropriate to explain critical factors to involve in different criminal behavior among young ages. Along with these theories, this study finds that

$>$ Age groups between 20-24 years are involved in committing more crimes compared to the age group between 15-19 years. On the other hand, younger prisoners aged 15-19 years and aged 20-24 years were more into drug offenses, theft, burning car giving threat and coercion than aged 25-29 years those were more into smuggling, corruption, murder, etc. An analysis of the type of crimes perpetrated revealed that all groups (15-19 years, 20-24 years, and 25-29 years) were high on stealing (theft) and drug offenses.

$>$ There is a positive correlation between education and crime. Low educated people are more prone to commit crimes compared to a highly educated people. Moreover, highly educated people have also committed the crime because of their adverse family circumstances.

$>$ Small business people, industrial worker, and student, are more prone to involve different criminal activities compared to private and government workers.

$>$ Prisoners both from urban and rural areas committed a different crime for different points of view and unusual circumstances. The incidence of the drug business, theft, robbery, murder, and sexual offenses are common in 
rural areas and poverty-stricken homes. That apart, the occurrence of corruption, smuggling, drug business, eve-teasing, trafficking and prostitution, threat and coercion, burning car etc. are mostly confined to the urban regions.

$>$ Levels of offending tend to be lower among married prisoners than unmarried young ages.

$>$ In recent time, a cybercrime which committed with the help of information technology has also been found among the young generation.

$>$ Disruptive families, family problems, bad relationships with family members are responsible for committing violent crimes.

$>$ Family crisis influence may lead the young people to behave abnormally and commit crimes such as drug-addicted, suicidal tendencies, acting with his/her family members just the same as his/her parents do.

$>$ Young ages from the broken family for divorce are more committed to different types of crime compared to the ruined families for the dead (father or mother or both) or separated family for internal conflict.

$>$ Due to poverty, young ages feel stain to achieve their required goal, and they try to gain their goal by involving different criminal activities.

> Media creates individualism, anomie, and also a cultural change that would be responsible for committing different crimes among young age. Furthermore, $71 \%$ of respondents didn't agree with the statement of the relationship between media and crime among young ages.

$>$ Living in a neighborhood with unfortunate and unsafe circumstances, an individual more prone to involve criminal activities than others.

$>$ Peer group and close associations badly influence on adolescents and young age group to involve criminal activities.

Finally, from the study, it is found that family relationship pattern and family crisis is a crucial indicator, and more responsible to stimuli young age prisoners to involve different types of crime than influenced by mass media, neighborhoods, peer group, and poverty in Bangladesh society.

\section{Conclusion}

This study shows that the involvement of young ages in different criminal activities is increasing day by day. There is no single cause or simple explanation for the involvement of young age prisoners in different criminal activities. This study finds some mentionable causes for the involvement of adolescents and youths in different criminal activities such as family relationship pattern, economic hardship of the family, quarrel and chaos between parents, influence of neighborhood and surrounding environment, influence of peers or classmates, influence of mass media and information technology etc. The policymakers of the country should be more concerned about it and to minimize the engagement of youths in criminal activities the establishment of safe and secured place for the adolescents and youths should be ensured. Parents should take care of their children by ensuring proper socialization. They should be conscious about the mixing of children in wider peer groups. Not only parents and guardians within the family but also other social and educational institutions including schools, college and universities should play their role properly to reduce the youths' engagement in criminality.

This study also tries to present some theoretical arguments of prominent sociologists and criminologists to understand the pattern and trend of youthful crimes. Some of these theoretical arguments are closely associated with pattern and recent trend of young age crime in Bangladesh. The policy makers and concerned authorities should understand all the key factors that influence the youths to commit crimes. Besides, law enforcement agencies and juvenile corrections centers should play pivotal role to control the youthful crimes in Bangladesh.

Finally, this study could be helpful for government, non- government organizations and agencies, local policy makers, community investment decisions by giving information about young age crime scenarios in Bangladesh, and to find out the solutions to reduce involving criminal activities among the young age groups.

\section{References}

Adler, F., Mueller, O. G., \& S.Laufer, W. (1991). Criminology. New York: McGraw-Hill, Inc.

Agnew, R. (1992). Foundation for a General Strain Theory of Crime and Delinquency. Criminology, 47-88. https://doi.org/10.1111/j.1745-9125.1992.tb01093.x

Chandan, M. S. (2015, september 5). The Daily Star. Retrieved December 23, 2019, from The Daily Star.com: https://www.thedailystar.net/star-weekend/spotlight/rotting-behind-bars-137293 
Chesterton, G. (2020, February 4). Effects of Family Structure on Crime. Retrieved February 15, 2020, from Marripedia: http://marripedia.org/effects_of_family_structure_on_crime

Chowdhury, A. R. (2016, May 15). Retrieved February 17, 2020, from The Daily Star: https://www.thedailystar.net/online/celebrating-shape-shifting-families-1224184

Consulting, C., \& Bright, C. (2018). The relationship batween family violence and youth offending. London: Local Government Association (LGA).

Cornelius, C. V., J. Lynch, C., \& Gore, R. (2017). Aging Out of Crime: Exploring the Relationship Between Age and Crime with Agent-Based Modeling. Spring Simulation Multi-Conference - Agent Directed Simulation (SpringSim-ADS) 2017, At Virginia Beach, VA. Suffolk.

Das, T. K. (2019, September 09). Retrieved April 17, 2020, from New Age Bangladesh: http://www.newagebd.net/article/84035/gangs-of-teens-cause-concern

Esiri, M. O. (2016). The Influence of Peer Pressure on Criminal Behaviour. IOSR Journal Of Humanities And Social Science (IOSR-JHSS), 2l(1), 8-14.

Gabriela, I. (2018). The influence of mass media on the development of deviant personality. Merit Research Journal of Medicine and Medical Sciences, 6(7), 109-112.

Gabriela, I. (2018). The influence of mass media on the development of deviant personality. Merit Research Journal of Medicine and Medical Sciences, 2-5.

Gauffin, K., Vinnerljung, B., Fridell, M., Hesse, M., \& Hjern, A. (2013). Childhood socio-economic status, school failure and drug abuse: a Swedish national cohort study. Society for the Study of Addiction, 108(8), 1441-1449. https://doi.org/10.1111/add.12169

Haque, I. E., \& Muniruzzaman, M. (2020). Impoverished Living Conditions and Crime in Society: A Study on Prisoners at Jamalpur District Jail, Bangladesh. Open Journal of Social Sciences, 8(3), 33-51. https://doi.org/10.4236/jss.2020.83005

Hasan, S. (2018, November 10). Retrieved February 16, 2020, from The independent: http://www.theindependentbd.com/printversion/details/174032

Jang, S. J., \& Agnew, R. (2015). Strain Theories and Crime. In S. J. Jang, R. Agnew, \& J. D. Wright (Ed.), International Encyclopedia of the Social\& Behavioral Sciences (2nd edition ed., pp. 495-500). Oxford: Elsevier. https://doi.org/10.1016/B978-0-08-097086-8.45088-9

Kader, M., \& Hussain, M. (2017). Criminology. Dhaka: Books 4 U.

Kanazawa, S., \& Still, M. C. (2002). Sociological Theory: Why Men Commit Crimes (and Why They Desist). American Sociological Association 2000. https://doi.org/10.1111/0735-2751.00110

Karzon, S. H. (2008). Theoretical and Applied Criminology. Dhaka: Palal Prokashoni and Empowerment through Law of the Common People (ELCOP).

Khan, M. J., \& Tipu, M. S. (2016, October 1). Retrieved February 16, 2020, from Dhaka Tribune: https://www.dhakatribune.com/bangladesh/2016/10/01/childrens-involvement-crime-rise

Khatun, M. N., \& Islam, M. J. (2018, December). CRIME IN BANGLADESH: A HISTORICAL OVERVIEW. Social Science Review, 35, 1-33.

Kim, J., \& Fletcher, J. M. (2018). The Influence of Classmates on Adolescent Criminal Activities in the United States. Deviant Behavor , 39(3), 275-292. https://doi.org/10.1080/01639625.2016.1269563

Liu, J. F., Messner, S., Zhang, L., \& Zhuo, Y. (2009). Socio-Demographic Correlates of Fear of Crime and the Social Context of Contemporary Urban China. American Journal of Community Psychology, 44, 93-108. https://doi.org/10.1007/s10464-009-9255-7

MacDonald, J., Bluthenthal, R. N., Golinelli, D., Kofner, A., Stokes, R. J., Sehga, A., .. Beletsky, L. (2009). Neighborhood Effects on Crime and Youth Violence. Santa Monica,: RAND Infrastructure, Safety, and Environment.

Majbahin, P. (2017, September 14). Retrieved February 16, 2020, from The daily Observer: https://www.observerbd.com/details.php?id=94664

Mednick, B. R., Baker, R. L., \& Carothers, L. E. (1990). Patterns of family instability and crime: The association of timing of the family's disruption with subsequent adolescent and young adult criminality. Journal of Youth and Adolescence, 19, 201-220. https://doi.org/10.1007/BF01537887 
Messner, S. F., \& Rosenfeld, R. (2007). Crime and the American Dream. Belmont: Thomas Higher Education.

Mia, B. (2019). Fundamentals of Criminology: New Dimension. Chittagong: Sui Juris.

Mundia, L., Matzin, R., Mahalle, S., Hamid, M. H., \& Osman, R. S. (2016). Contributions of sociodemographic factors to criminal behavior. Psychology Research and Behavior Management, 9, 147-156. https://dx.doi.org/10.2147\%2FPRBM.S95270

Psacharopoulos, G. (2007). The cost of school failure-A feasibility study. European Expert Network on Economics of Education.

Rahman, S. H. (2008). Theoretical and Applied Criminology (First ed.). Dhaka: Palal Prokashoni and Empowerment through Law of the Common People.

Rahman, S. H. (2008). Theoretical and Applied Criminology. Dhaka: Palal Prokashoni and Empowerment through Law of the Common People ( ELCOP).

Rengifo, A. F. (2017, November 1). CriminologySocial Disorganization. Retrieved February 13, 2020, from Oxford Bibliography: https://www.oxfordbibliographies.com/view/document/obo-9780195396607/obo-9780195396607-0008.xml

Rezvi, M. R. (2018, September 29). Retrieved February 17, 2020, from The Daily Sun: https://www.daily-sun.com/post/339513/Why-extended-family-breaking-down-in-Bangladesh

Rud, I., Klaveren, C. V., Groot, W., \& Brink, H. M. (2013). Education and Youth Crime: a Review of the Empirical Literature. Maastricht: The Top Institute for Evidence Based Education Research.

Shoemaker, D. J. (2018, january 1). Theories of Deliquency. Retrieved february 13, 2020, from New York:Oxford University Press: https://global.oup.com/academic/product/theories-of-delinquency-9780190841270?cc=us\&lang=en\&

Skardhamar, T., Savolainen, J., N. Aase, K., \& H. Lyngstad, T. (2015). Does Marriage ReduceCrime? Crime and Justice, 385-436. https://doi.org/10.1086/681557

Steinberg, L. (2015). Age of Opportunity: Lessons from the New Science of Adolescence. New York: Mariner Books.

Sutherland, E. H. (1947). Principles of criminology. (4th ed.). Chicago: J.B. Lippincott Co.

\footnotetext{
${ }^{i}$ Suddenly, my father divorced my mother, and my mother had no job. She left my father's house taking with me. She tried to empower herself by starting a crafting business. She earned some money, which is not enough to overcome our financial problem. Then I used to steal. And slowly I joined a robbery group in which all the members of this group were youths just like me. Once I gave up stealing with the request of my mother. But after completing my punishment, no one believed me. Relatives, neighbors, friends all started to consider me as a criminal, and I also started to think of myself as a criminal. I started doing more severe crimes than previously and joined a robbery group.

ii Due to poverty and unemployment, I moved from my village to Jamalpur Zilla, and started working as a day laborer in a construction building. I lived in a place just as slum area and I am deprived of all necessities and amenities of life. I could not send money in the village to support my parents. In this situation, I involved organized gangs in their different criminal activities. Then, I was able to spend more money for my family members, and they were pleased. However, they didn't know about my income source.

iii Living in a neighborhood with unfortunate and unsafe circumstances for raising an individual may cause to involve with criminal activities.Sometimes parents are bound to raise their children in a chaotic, hazardous environment because of low income. Neighborhoods contribute to the involvement with different crimes such as domestic violence, rape, eve-teasing, involving prostitution and trafficking, drug supplier, etc.

iv I am from a well-educated and economically solvent family. Though my family had no financial crisis, there was a problem with my parents. They often quarreled with each other which made me depressed. I had no siblings, and for this reason, I was entirely dependent on my friend circle. When I shared my family crisis with one of my friends and wanted suggestions from him to solve this problem, he suggested me to take drugs and alcohol to forget the issue. Slowly I was addicted, and to get easy access to buy drug, I started working as a drug dealer.

${ }^{v}$ I lived in a nuclear family. My father and mother both were going to the office. I felt alone, and I was addicted to my mobile phone. About 16 hours a day, I was busy with the mobile phone. Slowly, I was addicted to pornography and also used to go brothel. There was a gang who supplied girls for a prostitution business. I was also involved with women trafficking and prostitution business with this trafficking gang.
} 


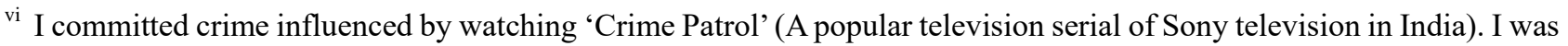
a blind fan of this serial and the style of doing different types of crime. I used to kidnapping girls and threading them to pay money according to my demand. I thought it is impossible to catch me, but I was wrong, the police grabbed me.

\section{Copyrights}

Copyright for this article is retained by the author(s), with first publication rights granted to the journal.

This is an open-access article distributed under the terms and conditions of the Creative Commons Attribution license which permits unrestricted use, distribution, and reproduction in any medium, provided the original work is properly cited. 